\title{
Functional independence in patients with chronic kidney disease being treated with haemodialysis ${ }^{1}$
}

\author{
Graziella Allana Serra Alves de Oliveira Oller ${ }^{2}$ \\ Rita de Cássia Helú Mendonça Ribeiro ${ }^{3}$ \\ Darlene Suellen Antero Travagim ${ }^{4}$ \\ Marcelo Aparecido Batista ${ }^{5}$ \\ Sueli Marques ${ }^{6}$ \\ Luciana Kusumota ${ }^{6}$
}

Purpose: This study has described and analysed the functional independence of the patients served in the haemodialysis services of a countryside town in the State of São Paulo, Brazil, using the Functional Independence Measure (FIM). Method: The population considered was that of 214 patients being treated with haemodialysis, assessed in 2011, by means of a social, demographic and clinical report, a Mini-Mental State Examination (MMSE) and also the FIM. Results: The mean age of the population under study was 58.01 years, while the mean FIM point score was 118.38 points, showing a level of complete or modified independence within this population. Even though the level of dependence found has been low, this can be highlighted, within the locomotion domain, in the activity of going up and down stairs (10.28\%). Age, complications arising from haemodialysis, and comorbidities show a negative correlation with FIM. Conclusion: Awareness of the level of functional independence of the patients being subjected to treatment with haemodialysis is essential in order to back up intervention for the improvement of nursing assistance provided to this population.

Descriptors: Renal Dialysis; Activities of Daily Living; Nursing.

\footnotetext{
1 Paper extracted from Master's Dissertation "Independência funcional e capacidade para o autocuidado de pacientes em tratamento hemodialítico" presented to Escola de Enfermagem de Ribeirão Preto, Universidade de São Paulo, WHO Collaborating Centre for Nursing Research Development, Brazil.

2 MSc, Assistant Professor, Nursing undergraduate course, Universidade Paulista, São José do Rio Preto, Brazil.

${ }^{3}$ PhD, Professor, Faculdade de Medicina de São José do Rio Preto, Brazil.

${ }^{4}$ Master's Student, Escola de Enfermagem de Ribeirão Preto, Universidade de São Paulo, WHO Collaborating Centre for Nursing Research Development, Brazil.

${ }^{5}$ RN, Prefeitura de Jardinópolis, Brazil.

6 PhD, Professor, Escola de Enfermagem de Ribeirão Preto, Universidade de São Paulo, WHO Collaborating Centre for Nursing Research Development, Brazil.
}

\author{
Corresponding Author: \\ Graziella Allana Serra Alves de Oliveira Oller \\ Universidade Paulista - UNIP \\ Av. Juscelino Kubitscheck, s/n \\ Jardim Tarraf II \\ CEP: 15091-450, São José do Rio Preto, SP, Brasil \\ E-mail: gra_enf@yahoo.com.br
}




\section{Independência funcional em pacientes com doença renal crônica em tratamento hemodialítico}

Objetivo: este estudo teve como objetivo descrever e analisar a independência funcional dos pacientes atendidos nos serviços de hemodiálise, de uma cidade do interior paulista, segundo a Medida de Independência Funcional (MIF). Método: a população foi de 214 pacientes em tratamento hemodialítico, avaliados em 2011, por meio de um questionário sociodemográfico e clínico, Miniexame do Estado Mental e MIF. Resultados: a idade média da população do estudo foi de 58,01 anos e a média da MIF foi de 118,38 pontos, evidenciando nível de independência completa ou modificada dessa população. Mesmo tendo sido baixo o nível de dependência encontrado, essa dependência destacou-se no domínio locomoção, na atividade subir e descer escadas $(10,28 \%)$. A idade, complicações relacionadas à hemodiálise e comorbidades apresentaram correlação negativa com a MIF. Conclusão: conhecer o nível de independência funcional dos pacientes em tratamento hemodialítico é primordial para subsidiar intervenções para a melhoria da assistência de enfermagem prestada a essa população.

Descritores: Diálise Renal; Atividades Cotidianas; Enfermagem.

\section{Independencia funcional en pacientes con enfermedad renal crónica en tratamiento de hemodiálisis}

Objetivo: este estudio describió y analizó la independencia funcional de los pacientes atendidos en los servicios de hemodiálisis de una ciudad del interior paulista, según la Medida de Independencia Funcional (MIF). Método: la población fue de 214 pacientes en tratamiento de hemodiálisis, evaluados en 2011, por medio de un cuestionario sociodemográfico y clínico, Mini examen del Estado Mental y MIF. Resultados: la edad Media de la población del estudio fue de 58,01 años y la media de la MIF fue de 118,38 puntos, evidenciando un nivel de independencia completa o modificada de esa población. Mismo habiendo sido bajo el nivel de dependencia encontrado, se destacó en el dominio locomoción, en la actividad ascender y bajar escaleras $(10,28 \%)$. La edad, complicaciones relacionadas a la hemodiálisis y mortalidades presentaron correlación negativa con la MIF. Conclusión: conocer el nivel de independencia funcional de los pacientes en tratamiento hemodiálisis es primordial para subvencionar intervenciones para la mejoría de la asistencia de enfermería prestada la esa población.

Descriptores: Diálisis Renal; Actividades Cotidianas; Enfermería.

\section{Introduction}

Chronic Kidney Disease (CKD) means that the patients need to follow certain restrictions and limitations, especially after dialysis treatment has been introduced. The people may become unable to carry out their normal daily routine duties, in which case the help of third parties becomes essential(1).

Haemodialysis is the type of treatment which is most commonly used nowadays, and $90.6 \%$ of all patients with CKD undergo treatment based on haemodialysis (2). This therapy interferes with the person's normal life, preventing or limiting the carrying out of daily routine activities, as these often cause physical incapacity and emotional problems ${ }^{(3)}$.

Thus, the issue of functional capacity has been one of the health components to be considered essential when appraising the health of the general population, especially of those who have chronic diseases like CKD ${ }^{(4)}$. Functional independence is defined as the capacity to do something unaided, which means the presence of motor and cognitive conditions that are satisfactory for the development of activities ${ }^{(5-6)}$. Appraisal by the health team is essential, as it relates the impact of the disease to the limiting conditions of the individual, thereby reflecting on his or her quality of life(6).

National and international studies have assessed the functional independence present in patients with CKD and reached the conclusion that these patients have functional limitations in some activities of daily life ${ }^{(7-8)}$. Appraising the level of functional independence helps the nurse to plan the assistance to be provided and also to 
act as effectively as possible in serving the population. It is supposed that there are countless difficulties faced by these people, whether through their dependence on the haemodialysis machine as also through their visits to doctors' consulting rooms, which interferes with the patient's daily activities(9).

Thus, the main purpose of this study is that of describing and analysing the functional independence of the patients served through the haemodialysis services from a countryside town in a city in the State of São Paulo, Brazil, based on the Functional Independence Measure (FIM).

\section{Methods}

A transversal study was performed, with the inclusion of the whole population of patients with CKD undergoing haemodialysis treatment and resident in the city of São José do Rio Preto, State of São Paulo, Brazil. Data was collected between May 2011 and August 2011.

The present study includes patients who have been diagnosed with CKD and having treatment with haemodialysis, aged over 18 and resident in the city of São José do Rio Preto, whose assessment of cognitive abilities is considered satisfactory through the application of a Mini-Mental State Examination (MMSE). Out of the original universe of 254 patients, a total of 40 were excluded: 16 patients with insufficient cognitive score on assessment (MMSE point score less than the cut-off points for the current educational level), 5 patients who received a kidney transplant, 1 patient who was transferred to another dialysis service, 2 patients who were transferred to peritoneal dialysis treatment, 5 patients who passed away, 3 patients who were hospitalised and 8 patients who declined to participate in the study. This means that there was a total exclusion of 40 patients, or $15.8 \%$ of the universe considered, meaning that a total of 214 patients did indeed participate in this study.

For data collection, the following instruments were used: 1) Mini-Mental State Examination (MMSE), used to judge the cognitive function of these patients and also reduce the possibility of risks in the understanding of these instruments; 2) Instrument of social, demographic and clinical characterisation; 3) Functional Independence Measure (FIM).

FIM has been used in rehabilitation centres in many different countries, such as Australia, Canada, France, Germany, Italy, Japan, Portugal and Israel(5,10). This means that the system has been widely used and accepted as a good measure of functional appraisal. In Brazil, its translation and reproductibility was completed in $2001^{(6)}$ and it was validated in $2004^{(5)}$.

The interviews were conducted in the respective dialysis units, during the sessions of haemodialysis, with a stable procedure lasting approximately 20 minutes. Contact was established with the interviewees, then the presentation and clarification of the research project was made, and written consent from the patients was obtained.

The analysis of the data was made using the statistical software package SAS ${ }^{\circledR 9}$.0. A descriptive statistical study was carried out using the data as supplied, and here it was possible to establish a characterisation as to the social, demographic and clinical variables. For the analysis of the correlation between the quantitative variables within the study, the statistical parameters used were Pearson's correlation coefficient and also the Exact Fisher Test, these being used to check for any link between the qualitative variables as listed and the different social, demographical and clinical variables. Confidence intervals with probabilities of $95 \%$ were used, while the significance level adopted was $p<0.05$.

The study was developed making sure of the compliance of the terms established in Resolution No. 196/96 of the National Commission for Ethics and Research (Comitê de Ética e Pesquisa) of the Brazilian Ministry for Health, having also been approved by the Commission for Ethics and Research of the Faculty of Medicine of São José do Rio Preto (FAMERP), according to opinion statement No. 043/2011 and protocol No. 0449/2011.

\section{Results}

The patients in the present study declared ages between 19 and 86, the mean age being 58.01 years. The sample comprised 108 adults (50.47\%) and 106 chronologically advantaged individuals (49.53\%), with a prevalence of male subjects (63.55\%) and people of the white race (55.14\%). The average educational level was 7.55 years of schooling. Most patients, 126 (58.88\%) lived with a partner.

In relation to the time subjected to haemodialysis as treatment, most of the patients (186 or $86.92 \%$ ) said they had been receiving this treatment for more than 6 months, with individual treatment times ranging from 1 to 260 full months. The average time with the diagnosis of CKD and the haemodialysis treatment time were 53.41 months and 41.13 months, respectively. 
For a total of 177 (82.71\%) patients, the Arteriovenous Fistula (AVF) was the current vascular access point for treatment using haemodialysis.

The most frequent comorbidities were: high blood pressure in 186 cases (86.92\%), diabetes mellitus in $97(45.33 \%)$ and others in 57 (26.64\%). The average number of comorbidities per patient stood at 2.3, and there was little change between adults and the chronologically advantaged. The most common physical complications related to CKD and treatment with haemodialysis, as reported by the patients, were: low blood pressure during haemodialysis in 137 cases (64.02\%); anaemia in 128 cases (59.81\%), general malaise in 124 cases (57.94\%), among others. The mean number of physical complications per patient was 4.7, and there was insignificant variation between the adults and the chronologically advantaged individuals.

It was observed that the mean total MIF score was 118.38 points, showing a complete or modified independence level within this population. On considering motor MIF, the average score was 84.31, while the mean cognitive MIF score was 34;07 (please see Table 1).

Here we must also mention that, in relation to the motor FIM domains in the categories of self-care there has been prevalence of the level of full independence. In relation to urine control the 214 patients (100\%) were classified in the modified independence level, as they were taking medication to control their urine, including diuretics, or were in a situation of anuria. In the category of locomotion, the task of going up and down stairs showed the lowest point score, with $46.26 \%$ of patients having complete independence and $10.28 \%$ of the patients having full assistance. Regarding the cognitive domain of FIM, subdivided into the categories of communication and social cognition, most cases showed a level of independence corresponding to complete or modified independence (Table 1).

Table 1 - Description of the Functional Independence Measure (FIM), its domains and respective categories among the 214 patients undergoing treatment through haemodialysis. São José do Rio Preto, São Paulo, Brazil, 2011

\begin{tabular}{|c|c|c|c|c|c|}
\hline Category (variation of scores) & Mean & Std Deviation & Median & Minimum & Maximum \\
\hline Motor MIF (13-91) & 84.31 & 11.67 & 89.00 & 27.00 & 90.00 \\
\hline Self-Care (6-42) & 39.93 & 5.71 & 42.00 & 11.00 & 42.00 \\
\hline Sphincter Control (2-14) & 12.76 & 0.69 & 13.00 & 8.00 & 13.00 \\
\hline Mobility (3-21) & 19.58 & 3.63 & 21.00 & 3.00 & 21.00 \\
\hline Locomotion (2-14) & 12.04 & 3.07 & 13.00 & 2.00 & 14.00 \\
\hline Cognitive FIM (5-35) & 34.07 & 1.65 & 35.00 & 24.00 & 35.00 \\
\hline Communication (2-14) & 13.73 & 0.72 & 14.00 & 10.00 & 14.00 \\
\hline Social Cognition (3-21) & 20.34 & 1.23 & 21.00 & 14.00 & 21.00 \\
\hline Total FIM (18-126) & 118.38 & 12.40 & 123.00 & 58.00 & 125.00 \\
\hline
\end{tabular}

A negative correlation was found between the average total FIM score and the age variable. In Figure
1 below we can see that, with an increase in age, there is a decline in the degree of functional independence.

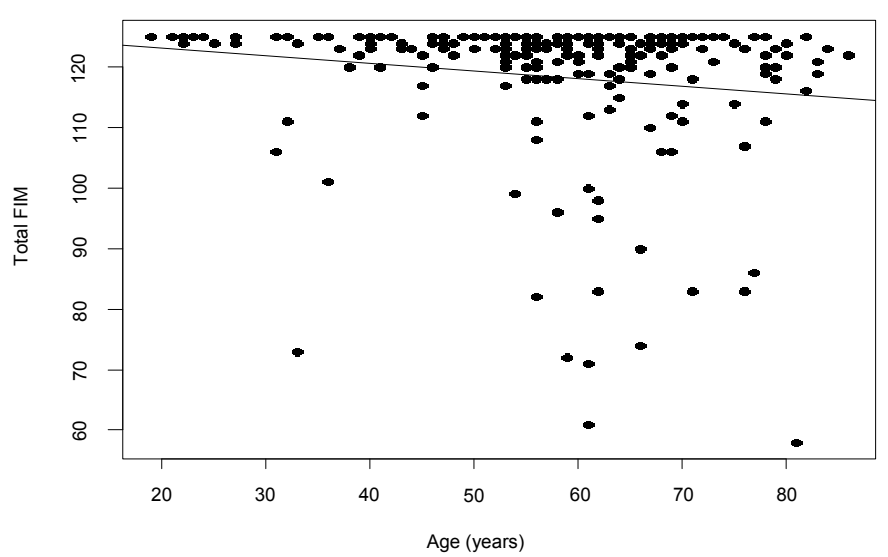

Figure 1 - Distribution of FIM scores in relation to the ages of the 214 patients being treated by haemodialysis. Pearson correlation coefficient (-0.14), p-value (0.03). São José do Rio Preto, São Paulo, Brazil, 2011 
Table 2 shows the correlation between the FIM and the social, demographic and clinical variables: age, duration of treatment by haemodialysis, complications arising from CKD and haemodialysis treatment, and comorbidities. Here we can see a negative correlation between these variables, showing that as the number of comorbidities and complications increases, the functional independence of the patients declines, while the comorbidities and complications have a positive correlation.

Table 2 - Pearson correlation coefficients between social, demographic and clinical variables and total FIM scores for the 214 patients being treated by haemodialysis. São José do Rio Preto, Brazil, 2011

\begin{tabular}{|c|c|c|c|c|c|c|c|c|c|c|}
\hline & \multicolumn{2}{|c|}{ Age } & \multicolumn{2}{|c|}{$\begin{array}{c}\text { Duration of } \\
\text { treatment by HD }\end{array}$} & \multicolumn{2}{|c|}{ Total FIM } & \multicolumn{2}{|c|}{$\begin{array}{l}\text { Complications } \\
\text { Related to HD }\end{array}$} & \multicolumn{2}{|c|}{ Comorbidities } \\
\hline & $\mathbf{r}$ & $\mathrm{p}$ & $\mathbf{r}$ & $\mathbf{p}$ & $\mathbf{r}$ & $\mathbf{p}$ & $\mathbf{r}$ & $\mathbf{p}$ & $\mathbf{r}$ & $\mathbf{p}$ \\
\hline Age & 1.00 & - & 0.01 & 0.90 & -0.14 & $0.03^{*}$ & 0.06 & 0.40 & 0.12 & 0.08 \\
\hline Duration of treatment by $\mathrm{HD}$ & 0.01 & 0.90 & 1.00 & - & -0.12 & 0.09 & -0.10 & 0.15 & 0.03 & 0.62 \\
\hline Total FIM & -0.14 & $0.03^{*}$ & -0.12 & 0.09 & 1.00 & - & -0.18 & $0.01^{*}$ & -0.28 & $\square 0.01^{*}$ \\
\hline Complications Related to HD & 0.06 & 0.40 & -0.10 & 0.15 & -0.18 & $0.01^{*}$ & 1.00 & - & 0.25 & $<0.01^{*}$ \\
\hline Comorbidities & 0.12 & 0.08 & 0.03 & 0.62 & -0.28 & $\square 0.01^{*}$ & 0.25 & $<0.01^{*}$ & 1.00 & - \\
\hline
\end{tabular}

*p-value $<0.05$

Table 3 shows the mean levels of functional independence, according to different clinical variables.
A statistical significance has been found between FIM scores, according to diabetes mellitus.

Table 3 - Description of average scores of FIM and t-Student tests between the clinical variables of the 214 patients undergoing treatment with haemodialysis. São José do Rio Preto, State of São Paulo, Brazil, 2011

\begin{tabular}{|c|c|c|c|c|c|c|}
\hline & \multicolumn{4}{|c|}{ TOTAL MIF } & \multirow{2}{*}{\multicolumn{2}{|c|}{$\mathrm{Cl}(95 \%)$}} \\
\hline & Mean & StD & Differences & p-value & & \\
\hline \multicolumn{7}{|c|}{ Diabetes Mellitus } \\
\hline No & 120.82 & 9.85 & \multirow{2}{*}{5.22} & \multirow{2}{*}{$<0.01^{*}$} & \multirow{2}{*}{1.93} & \multirow{2}{*}{8.51} \\
\hline Yes & 115.43 & 14.42 & & & & \\
\hline \multicolumn{7}{|l|}{ Hypertension } \\
\hline No & 116.68 & 15.47 & \multirow{2}{*}{-2.33} & \multirow{2}{*}{0.36} & \multirow{2}{*}{-7.28} & \multirow{2}{*}{2.63} \\
\hline Yes & 118.63 & 11.90 & & & & \\
\hline \multicolumn{7}{|c|}{ Duration of treatment with HD } \\
\hline$\leq 6$ months & 119.14 & 8.91 & \multirow{2}{*}{0.79} & \multirow{2}{*}{0.75} & \multirow{2}{*}{-4.16} & \multirow{2}{*}{5.76} \\
\hline$\square 6$ months & 118.26 & 12.86 & & & & \\
\hline \multicolumn{7}{|l|}{ Haemoglobin } \\
\hline Anaemia $^{\dagger}$ & 118.59 & 11.68 & \multirow{2}{*}{1.05} & \multirow{2}{*}{0.62} & \multirow{2}{*}{-3.09} & \multirow{2}{*}{5.19} \\
\hline Normal & 117.55 & 15.00 & & & & \\
\hline \multicolumn{7}{|l|}{ Hematocrit } \\
\hline Anaemia $^{\ddagger}$ & 118.48 & 11.34 & \multirow{2}{*}{0.24} & \multirow{2}{*}{0.89} & \multirow{2}{*}{-3.14} & \multirow{2}{*}{3.61} \\
\hline Normal & 118.24 & 13.71 & & & & \\
\hline
\end{tabular}

$*$ p-value $<0.05$

† anaemia: haemoglobin values of less than $13.0 \mathrm{~g} / \mathrm{dL}$ for males and $12.0 \mathrm{~g} / \mathrm{dL}$ in females and also in males aged over 65

₹ anaemia: haematocrit values below $40 \%$

Patients with diabetes have lower functional independence when compared with non-diabetic patients.

\section{Discussion}

Even though the results suggest that most categories of FIM show complete or modified independence, it is considered relevant to look at the subcategories which show the lowest average scores, characterising the patients with some degree of dependence for locomotion when going up or down stairs, to get dressed above the waist and also to get dressed below the waist, especially considering the characteristics of the population studied.

In the self-care item, the item of personal hygiene has a high level of difficulty for chronologically 
advantaged patients with cognitive deficit ${ }^{(11)}$ and also for those patients who have had a stroke(12), different from the chronic renal patients of this study. It is also worth mentioning that, as a criterion for selection within this research study, an instrument for cognitive appraisal was used (MEEM) before the data were collected, in order to fully detect cognitive faults and losses that could affect the study; hence, the patients included had their cognitive functions preserved, which could have contributed to the results which showed higher point scores for independence.

In relation to sphincter control, the task for controlling flow of urine obtained $100 \%$ modified independence, this category also including all patients in situations of anuria or with a residual urinary output. The chronic renal patient shows changes in urination, mainly related to reduction in the volume of urine ${ }^{(13)}$.

For control of defecation, there was a high level of complete independence and modified independence. According to the FIM criteria, patients who use medication to improve their control of intestinal function are included in the category of modified independence, while the use of food is related to complete independence. This is an issue that warrants further investigation in future studies, as chronic renal patients have recommended changes in their eating habits, restrictions on liquids, and also several medications that can cause problems in intestinal function, both obstipation and diarrhoea. A study carried out with 448 patients undergoing dialysis treatment has detected a prevalence of intestinal obstipation in 33.5\% of the patients undergoing haemodialysis ${ }^{(14)}$.

Turning to mobility, most patients have shown complete or modified independence, which is in line with the findings of the study conducted with CKD patients undergoing haemodialysis treatment, in which only $18.4 \%$ of the patients that underwent haemodialysis showed some level of dependence in carrying out this task. For the task of going up and going down stairs, within the locomotion domain, the scores obtained were lower, and $10.28 \%$ of the patients had total assistance for this task, with similar data being found in the specialised literature ${ }^{(7,15)}$.

One common problem in cases of CKD is renal osteodystrophy which, when established, can result in pain, bone fractures and bone deformations, which in the case of chronologically advantaged patients can often be mistaken for the osteopathies that are common to the ageing process ${ }^{(16)}$.

Studies carried out in the United States have shown that patients undergoing substitutive renal therapy had an incidence of fractures that was 4.4 times larger than in the general population(17). Patients with CKD and hip fractures had greater mortality when compared with chronic renal patients with cardiovascular complications without fractures ${ }^{(18)}$.

In spite of the high percentage of patients who are being treated for renal osteodystrophy, we see a lack of suitability for the control of the indicators for mineral metabolism disorders. The complications arising from renal osteodystrophy can have an influence on the independence of these patients, as they directly interfere with the activities of daily routine, such as going up and going down stairs.

Functional independence has shown inverse correlation with age. In a study carried out with chronologically advantaged people in the city of São Paulo, it was proved that to be aged over 65 is a risk factor for functional dependence. People aged between 65 and 69 have about 1.9 times more chance of showing a decline in functional independence, with this factor increasing gradually, reaching a peak of about 36 times, among patients aged over 80 years old(19).

The ageing of the population can also be related to an increase in the occurrence of diseases among the population, greater incapacity, and also an increase in the use of health services. The maintenance of functional independence has shown true results at any stage of life, including more advanced age ${ }^{(19)}$. The maintenance of functional independence could have important implications to improve the quality of life of senior citizens, and is also related to the ability for the patients to keep themselves occupied, perform pleasant activities and also activities that are essential within their daily routine ${ }^{(20)}$.

CKD and its treatment can cause physical and emotional limitations, thus interfering in the patients' lives, limiting or even preventing the carrying out of the patient's daily tasks. Age is a variable that could interfere with the independence of this patient, as it has a negative connection with the extent of care taken for the execution of an activity.

In clinical practice, there is clear evidence of the limitation on daily activities as age advances. It is also worth mentioning that dependence for activities of daily life is a factor that can be changed through prevention and rehabilitation and, even though the main concepts of prevention in the health sector have been assimilated by the professional people working in the area, we still see great difficulty in operationalisation, especially when this refers to those groups of chronic patients, like those with CKD ${ }^{\text {(21-22). }}$ 
The maintenance of functional capacity can have implications on the quality of life of patients with CKD, as this is related to the capacity for the individual person to keep himself or herself within the community, enjoying independence on a daily basis ${ }^{(23)}$. The patient who is being treated by haemodialysis has restrictions on times, physical limitations and also psychological restrictions, among other changes that could have an influence on the execution of these activities on a routine basis.

When the effect of the patient's sex is researched, in relation to total FIM scores, we see that males have a higher average when compared to females, which means that men have greater functional independence than women. Among the chronologically advantaged, the gender variable is strongly associated to the presence of dependence, the chance for women being twice that of men(19).

The diseases that cause CKD and other comorbidities that progress during the time spent in haemodialysis can lead to physical incapacitation, emotional problems and social problems for the afflicted patients(21). The mean number of comorbidities for the population studied was 2.3 and, when analysed in relation to the gender, being male brings a 2.21 factor of increase of comorbidities, when compared to being female.

High blood pressure and diabetes mellitus, as DCNTs, are a constant concern shown by nephrology specialists, due to the high rate of occurrence and prevalence within the general population and also being the main causes of $\mathrm{CWD}^{(2,13)}$.

Even though in the present study no relationship has been found between high blood pressure and FIM, it must be mentioned that, in general, the comorbidities have a relationship with functional independence of patients who are having treatment with haemodialysis. There has been confirmation of a negative correlation between these variables, showing that the more comorbidities there are, the lower the degree of functional independence.

Chronic illnesses have a strong influence on the functional independence of the patients, especially in the case of the chronologically advantaged. A study has shown that having high blood pressure brings a $39 \%$ increase in the likelihood of the senior citizen being dependent for the carrying out of instrumental activities in daily life. Other diseases, including heart disease, arthropathy and lung disease, bring increases of $82 \%, 52 \%$ and $50 \%$, respectively, to the chance of this population being dependent for daily activities ${ }^{(24)}$.
According to the Brazilian Nephrology Society, the main causes of CKD were systematic hypertension, with $35 \%$, and diabetes mellitus, with $28 \%{ }^{(2)}$. Patients with diabetes mellitus had a lower rate of functional independence. Studies have shown an association between diabetes mellitus and the presence of early indicators of functional decline, which limits the execution of simple activities of the daily lives of the patients concerned(25).

It is also worth stressing that the association between diabetes mellitus and functional independence is due to multiple factors, as this illness is closely linked to vascular and neuropathic complications which, as a result, affect functional independence. Thus, diabetics with CKD undergoing dialysis treatment are patients of high complexity, and the seriousness of the illness and the treatment thereof may have an influence on the functional independence of this individual(24).

\section{Conclusion}

The present study has made it possible to get to know the profile of the patients who are undergoing haemodialysis treatment and are resident in the city of São José do Rio Preto, State of São Paulo, Brazil, and their degrees of functional independence. The investigation of functional independence in patients with CKD is a recent issue for the professional people in the nursing professional, but the awareness of the needs of these patients in relation to the execution of their daily activities helps the nurse in establishing systematics for the assistance provided to this population.

Variables such as gender, age, complications arising from the haemodialysis, and comorbidities in general, specifically diabetes mellitus, are important factors in establishing the functional independence of this population. Functional independence, as appraised by the FIM, of patients with CKD being treated by haemodialysis and resident in the city of São José do Rio Preto, State of São Paulo, showed as the main results a level of complete or modified independence of this population.

These results are relevant to the health team, especially for nursing professionals, as this can help them to plan and implement intervention for maintenance and/or improvement of assistance provided to chronic renal patients undergoing haemodialysis. It is also worth mentioning that the nursing professional needs to have a style of action that is wider in scope and also active in the prevention of jeopardy of, together with the maintenance 
and restoration of, the functional independence of these patients, as this type of professional person is considered an active agent in relation to patient care.

\section{References}

1. Cesarino CB, Oliveira GASA, Shoji S, Garcia KAB. $\mathrm{O}$ autocuidado de clientes portadores de hipertensão arterial em um hospital universitário. Arq Ciências Saúde. 2004;11(3):146-8.

2. Sesso RC, Lopes AA, Thomé FS, Lugon JR, Santos DR. 2010 report of the Brazilian dialysis census. J Bras Nefrol. 2011;33(4):442-7.

3. Kusumota L, Marques S, Haas VJ, Rodrigues RAPI. Adults and elderly on hemodialysis evalution of health related quality of life. Acta Paul Enferm. 2008;21:152-9. 4. Ministério da Saúde (BR). Cadernos de Atenção Básica: Envelhecimento e saúde da pessoa idosa. Brasília (DF); 2006.

5. Riberto M, Miyazaki MH, Jucá SSH, Sakamoto H, Pinto PPN, Battistella LR. Validação da versão brasileira da medida de independência funcional. Acta Fisiátrica.2004;11(2):72-6.

6. Riberto M, Miyazaki MH, Jorge D Filho, Sakamoto $\mathrm{H}$, Battistella LR. Reprodutibilidade da versão brasileira da medida de independência funcional. Acta Fisiátrica.2001;8(1):45-52.

7. Mortari DM, Scapini KB, Menta M, Rockembach CWF, Duarte $A$, Leguisano CP. Independência funcional de indivíduos com doença renal crônica terminal submetidos à hemodiálise. Rev Inspirar. 2009;1(3):39. Suplemento 1. 8. Rocco DG, Mercieri A, Yavuzer G. Multidimensional health-status assessment of chronic hemodialysis patients: the impact on quality of life. Europa Medicophysica. 2006;42(2):113-9.

9. Bezerra KV, Santos JLF. Daily life of patients with chronic renal failure receiving hemodialysis treatment. Rev. Latino-Am. Enfermagem. 2008;16(4):686-91.

10. Ottenbacher $\mathrm{KJ}$, Hsu $\mathrm{Y}$, Granger $\mathrm{CV}$, Fiedler RC. The reliability of the functional independence measure: a quantitative review. Arch Phys Med Rehab. 1996;77(12):1226-32.

11. Talmelli LFS, Gratão ACM, Kusumota L, Rodrigues RAP. Functional Independence level a d cognitive déficit in elderly individuals with Alzheimer's disease. Rev Esc Enferm USP. 2010;44(4):933-9.

12. Viana FP, Lorenzo AC, Oliveira EF, Resende SM. Medida de independência funcional nas atividades de vida diária em idosos com sequelas de acidente vascular encefálico no Complexo Gerontológico Sagrada Família de Goiânia. Rev Bras Geriatria Gerontol. 2008;11(1);17-28.

13. Riella MC. Princípios de nefrologia e distúrbios hidroeletrolíticos. 5.ed. Rio de Janeiro: Guanabara Koogan; 2010. 1246 p.

14. Anzuategui LSY, Hoffmann K, Martins C, Maciel MARM, Anzuategui RR, Riella MC. Prevalência da obstipação intestinal em pacientes em diálise crônica. J Bras Nefrolo. 2008;30(2):137-43.

15. Hsieh RL, Huang HY, Chen SC, Lin WH, Wu CW, Chang $\mathrm{CH}$, et al. Changes in physical functional performance and quality of life in hemodialysis patients in Taiwan: a preliminary study. J Nephrol. 2010;23(1):41-8.

16. Ministério da Saúde (BR). Osteodistrofia Renal. Portaria SAS/MS n69, de 11 de fevereiro de 2010. Brasília; 2010.

17. Alem AM, Sherrard DJ, Gillen DL, Weiss NS, Beresford SA, Heckbert SR, Wong C, Stehman-Breen $C O$. Increased risk of hip fracture among patients with end-stage renal disease. Kidney Int. 2000;58(1):396-9. 18. Mittalhenkle A, Gillen DL, Stehman-Breen CO. Increased risk of mortality associated with hip fracture in the dialysis population. Am J Kidney Dis. 2004;44(4):672-9.

19. Rosa TEC, Benício MHD, Latorre MRDO, Ramos LR. Determinant factors of functional status among the elderly. Rev Saúde Pública. 2003;37(1):40-8.

20. Veras R. Population aging today: demands, challenges and innovations. Rev Saúde Pública. 2009;43(3):548-54. 21. Kusumota L, Oliveira MP, Marques S. Older adults undergoing dialysis. Acta Paul Enfermagem. 2009;22:546-50.

22. Monteiro CR, Faro ACM. Functional evaluation of aged with fractures at hospitalization anda t home. Rev Esc Enferm USP. 2010;44(3):719-24.

23. Li M, Porter E, Lam R, Jassal SV. Quality improvement through of interdisciplinary geriatric hemodialysis rehabilitation care. Am J Kidney Dis. 2007;50(1):90-97.4e 24. Alves LC, Leimann BCQ, Vasconcelos MEL, Carvalho MS, Vasconcelos AGG, Fonseca TCO, et al. The effect of chronic diseases on functional status of the elderly living in the city of São Paulo, Brazil. Cad Saúde Pública. 2007;23(8):1924-30.

25. Rekeneire N, Resnick HE, Schwartz AV, Schorr RJ, Kuller LH, Simonsick EM, et al. Diabetes is assiciated with subclinical functional limitation in nondisabled older individuals. Diabetes Care. 2003;26(12):3257-63. 